\title{
$\underbrace{6}_{\text {IJPBA }}$
}

Contents lists available at www.ijpba.in

International Journal of Pharmaceutical and Biological Science Archive

NLM (National Library of Medicine ID: 101738825)

Index Copernicus Value 2019: 71.05

Volume 9 Issue 1; January-February; 2021; Page No. 102-107

\section{Lannea coromandelica: An Overview}

\author{
J. N. Gunjal *, Prof. Mrs. M. S. Patil, Prof.Dr. K.P.Chittam
}

Department of Pharmacognosy, DCS's A. R. A. College of Pharmacy, Mumbai -Agra Highway, Nagaon, Dhule - 424001, Maharashtra, India

\section{Conflicts of Interest: Nil}

Corresponding author: J. N. Gunjal

DOI https://doi.org/10.32553/ijpba.v9i1.181

\begin{abstract}
Plants serve humans as primary sources for food, shelter and medicines. So understanding the plant uses in treating the diseases is very important for leading a healthier life. Our ancestors have used many plants as medicines and there is a need to provide scientific evidence for the same. Lannea coromandelica from family Anacardiaceae is one of the potent remedial plant. It is known as Modhad or Moi in Vernacular language and is found to be distributed throughout India. It is one of the common plants of deciduous forest and plains .It was extensively used by the tribes all over India to treat various diseases. Many investigations on the chemistry of the plant have been done. This article reviews about the plant L. coromandelica.
\end{abstract}

Keywords: Lannea coromandelica, Anacardiaceae

\section{Introduction}

Herbal medicines have been used throughout the beginning of human history and played a pivotal role in the prevention and treatment of various diseases. Ancient, Indian medicinal systems viz. Ayurveda, Siddha, Unani, and local health traditions provides a strong base for the utilization of a large number of plants in terms of safety and effectiveness leads for the management and treatment of different disease conditions. A large number of herbs \& herbal formulations are used as rejuvenators. [N. Santhi Priya et. al, 2015]. The Lannea

Genus: Lannea
Species: coromandelica
Family: Anacardiaceae.
English: Indian Ash Tree, Moya, Wodier
Harathi: shimati , moi
Sanskrit: Jhingini
Konkani: Moi
Gujarati: Mavedi

coromandelica is a tropical tree commonly called as Indian ash tree. This plant is reported to be used in the traditional medicine for the treatment of various ailments. [R. Sathish, et al, 2010]. A number of researchers attempted to reveal the claims of the plant and succeeded in proving the same. Still many of the traditional uses of this plant are devoid of a recorded scientific proof. This article features the review of pharmacognostical study and the traditional uses of Lannea coromandelica [Reddy et al,2011].

2. Plant profile 


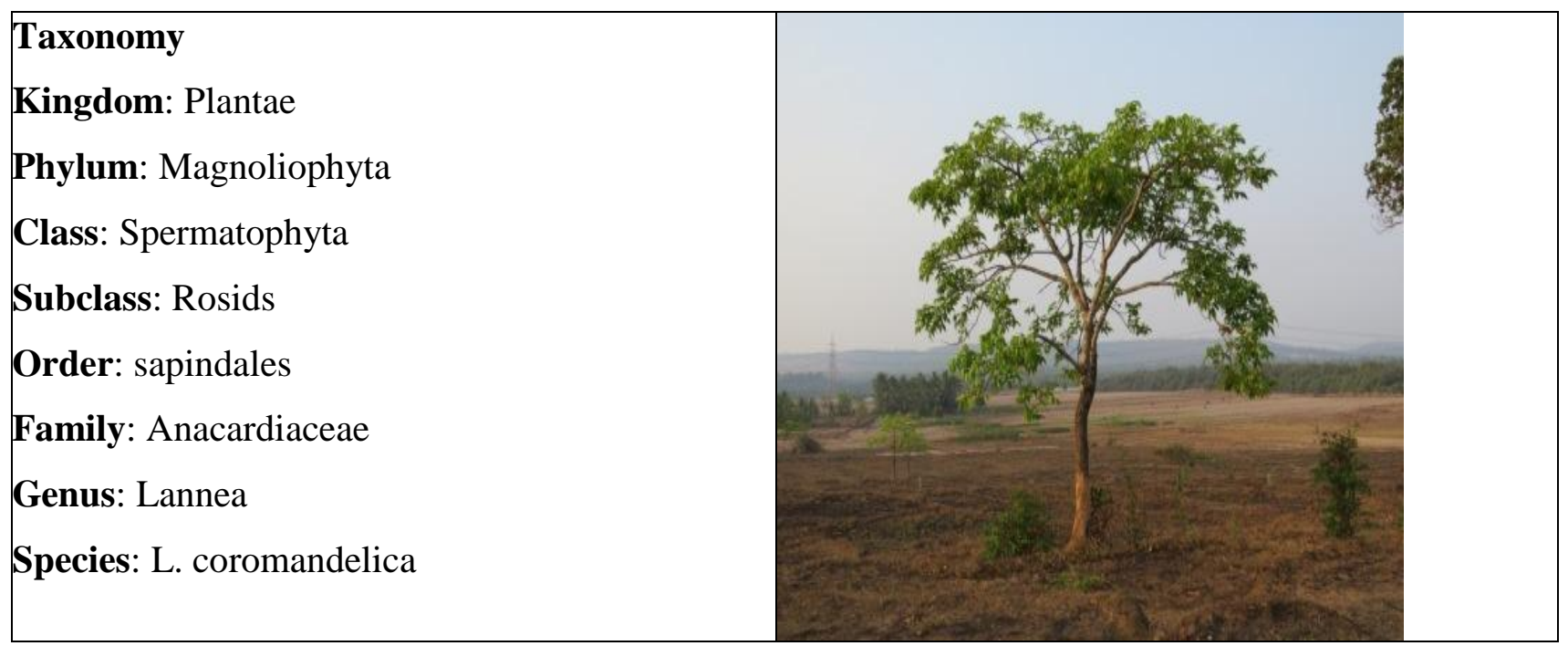

\section{Etimology:}

The genus Lannea is named in the honor of the French man Lannes de Montebelio who sent the plant from Japan to France around 1870 and the species coromandelica is named behind Coromandel, the coast of southern eastern part of India .[Md. Arif Wahid, 2009]

\section{Description}

Trees or shrubs each with inconspicuous flowers, highly poisonous, sometimes foul smellingresinous or milky sap. Resin-canals located in the inner fibrous bark of plants fibrovascularsystem found in the stems, roots and leaves is characteristic of all members of this family; resin canals located in the pith is a characteristic of many of the cashew family species and severalspecies have them located in the primary cortex or the regular bark.The wood of Anacardiaceae has the frequent occurrence of simple small holes in the vessels, occasionally in some species side by side with scalariform holes.[John $\mathrm{H}$ Beaman, 1986]. The simple pits are located along the vessel wall andin contact with the parenchyma.Leaves are alternate or rarely opposite and without stipule.Flowers grow at the end of a branch or stem or at an angle from where the leaf joins the stem andhave bracts. Often with this family bisexual and male flowers on some plants, and bisexual andfemale flowers on others or flowers having both stamens and pistils. [Bharath Kumar,2010] Calyx with 3 to 7 cleftsepals and the same number of petals, occasionally no petals, overlapping each other in the bud.Stamens twice as many or equal to the number of petals, inserted at the base of the fleshy ring orcup-shaped disk, and inserted below the pistil(s). stamen stalks separate, anthers able to move.Flowers have the ovary free, but the petals and stamen are borne on the calyx.In the stamenateflowers, ovaries are 1-celled. In the pistillate flowers, ovaries are 1-celled or sometimes 4-5-celled. 1-3 styles and 1 ovule in each cavity.Fruits rarely opening at maturity and are most often drupes.Seed coats are very thin or are crust like. Little or no endosperm. Fleshy cotyledons. Solitaryseeds with no albumen around the embryo.[Manzur et al ,2009]

\section{Distribution}

Anacardiaceae are found in dry to moist, mostly lowland habitats, primarily in the tropics and subtropics but extending into the temperate zone. The family is native to the western hemisphere (from southern Canada south to Patagonia), Africa, southern Europe, temperate and tropical Asia, tropical and subtropical Australia, and most of the Pacific Islands. The family is absent from northern Europe, temperate and arid Australia, New Zealand, the Galapagos Islands, and extreme desert and high elevation habitats.[Prabhat et al ,2010].

\section{Phenology}

- Flowering season: From March to May

- Fruiting season: From May to October.

- Seeding season: From May to October.

- Leaves falling: During the hot season.

\section{Reproduction and dispersal}

\section{Sex distribution:}

Lannea coromandelica is monoecious, with unisexual (male or female) flowers on the same individual.

\section{Mode of pollination:}

Lannea coromandelica is pollinated by a wide variety of insects. 


\section{Seed dispersal:}

The seeds of Lannea coromandelica are dispersed by various fruit-eating birds and mammals.

\section{Ecology:}

Lannea coromandelica is found in deciduous forests from the coastal plains up to $1800 \mathrm{~m}$ on the hill slopes

\section{Growing conditions}

Like the Mango, the tree thrives in humid tropical and subtropical areas growing up to 2 metres in a single growing season. It grows on all types of soil, as long as they are well drained. It has been noted that some trees can suffer from some nutritional disorders if the soil is too alkaline. Trees are cold sensitive when small and should be protected from serious frost and strong wind. Trees do best in full sun, but will produce some fruit in light shade. As a large and vigorous tree they prefer not be planted underneath other large trees and unlike some mango varieties they are not too fussed on salt spray.[Venkata et al, 2008]

\section{Reforestation:}

Planting advice and requirements: Lannea coromandelica is a fast growing species and it is able to flourish in a wide range of soils but all soils need to be free draining. It thrives in open areas.Lannea coromandelica requires a sunny position in a well-drained soil.The species is propagated by seeds and cuttings.

Seed treatment: 24 hours of soaking in water accelerates the germination process. The seeds viability is short so they have to be sown as soon as possible.

\section{Cultivation Details}

Succeeds in tropical and subtropical zones at elevations up to 1,800 metres. Grows best in areas where the mean annual temperature falls within the range $32-40^{\circ} \mathrm{c}$, but can tolerate $8-47^{\circ} \mathrm{c}$. Plants are killed at temperatures below $-2.5^{\circ} \mathrm{c}$. Prefers a mean annual rainfall of $1,200-2,000 \mathrm{~mm}$, tolerating 600 $3,800 \mathrm{~mm}$. Grows best in a sunny position. Succeeds in most soils of moderate fertility, tolerating poor soils. Prefers a $\mathrm{pH}$ in the range $5-6.5$, but tolerates 4.5 - 8. In its more common, dry woodland environment, the tree is usually small and somewhat ungainly - in moister conditions, however, it can become a handsome, spreading tree. The valuable heartwood is generally only formed in sufficient quantity from trees grown in moister conditions. The tree is resistant to fire. A dioecious species, both male and female forms need to be grown if seed is required.[Katupotha et al, 2015].

\section{Uses}

\section{Medicinal Uses:}

Lannea coromandelica is used in Ayurveda and Siddha medicines.

The boiled leaves are applied for local swellings and body pains. The bark decoction is used as a gargle for aphthae of the mouth and for toothache [Merlin Franco F et. al, 2009]. The fruits are used in treatment of fish poisoning. [ Heda Nilesh et. al, 2009].The juice of bark and leaves is applied to ulcers and swellings. [ Prabhat Kumar Rai et. al 2010] . The stem bark is used as an antifertility drug. it is also used in treatment of seminal weakness and excessive seminal emission [Md. Manzur-ul-Kadir Mia et al 2009]. The leaf paste is applied to treat sprains and bruises ,elephantiasis, inflammation, neuralgia. The bark is useful in cuts, wounds, bruises, ulcers, opthalmia, gout, ulcerative stomatitis, odontalgia, sprains, diarrhea and dysentery, impotency [Mohammad S. Rahman et al , 2008]. The paste of stem bark is applied on cuts and burns. The crushed bark extract is taken to cure dysentery. The bark paste is given in stomach pain.The bark lotion is also useful in leprous ulcers. [Bharath Kumar R, 2010]. Leaf juice was also claimed to be used as antidote in coma caused by narcotics

[http://www.goacom.com/goafoundation/biodiversit y]. In siddha system stem bark decoction used in menorrhagia and metarrhagia [Khare, 2007]. The fruits paste is therapeutically used for bone fractures by tribes in eastern Ghat of Andhra Pradesh.[ Venkata ratnam $\mathrm{K}$ et al 2008].

\section{Edible Uses:}

Young leaves and sprouts are Eaten as a vegetable. Eaten as a lalab (a vegetable salad served with sambal) with rice. The gum obtained from the trunk is often used in confectionery. The powdered bark is used as flavour [Ken Fern, 2014].

\section{Veterinary Uses:}

The crushed bark is used as a bandage on wounds and cuts. [Quattrocchi, 2012,].

\section{Handicrafts}

The wood of Lanneacoromandelica is resistent to termites and it is used for house building, furniture, rice pounders, for carving and turnery [Dastur, 2006]. A resin called jhingam gum is obtained from the stems and it is used for calico printing, as a size 
for paper. It is also used as a flocculating agent for the clarification of sugar-cane juice. The bark contains tannins so it is used for tanning, as a dye and to preserve fishing nets.[Ken Fern, 2014].

\section{Chemical constituents}

The plant was reported to contain various compounds like Carbohydrates including Gums, Proteins, Glycosides, Terpenoids, Polyphenols. Preliminary phytochemical analysis of the bark revealed the presence of Terpenoids and Flavonoids. [Md. Manzur et al ,2009] The three aldobiouronic acids constitute 4-O-(a-D-galactopyranosyluronic acid)-D-galactose, 6-O-(B-D-glucopyranosyluronic acid)-D-galactose, and 6-O-(4-O-methylDglucopyranosyluronic acid)-D-galactose. Controlled acid hydrolysis revealed the Linkage System in the degraded gum which was 3-O- $\beta$-Larabinofuranosyl-L-arabinose, 3-O-BLarabinopyranosyl- L-arabinose, 3-a-Dgalactopyranosyl-L-arabinose, 3-O- $3-\mathrm{D}-$ galactopyranosyl-D-galactose, and 6-O- $3-\mathrm{D}-$ galactopyranosyl-D-galactose. The methanolysis of the gum resulted in neutral polysaccharide in which the 4-O-methyl derivatives namely 2,3,4-tri-Omethyl-Lrhamnose, 2,3,5- and 2,3,4-tri- and 2,5-diO-methyl-L-arabinose, 2,3,4,6-tetra-, 2,3,6-, 2,4,6-, and 2,3,4-tri-, and 2,6- and 2,4-di-O-methyl-Dgalactose, 2,3,4-tri-O-methyl-D-glucuronic acid and 2,3,4-tri-O-methyl-D-galacturonic acid were identified. [Anderson et al, 1973] In molar terms this methylated polysaccharide from the gum on hydrolysis yields one mole of 2,3,4,6-tetra-Omethyl-D-galactose, four moles of 2,3,6-tri-Omethylo-galactose, three moles of 2,6-di-O- methylD-galactose and two moles of 2,3,5-tri-Omethyl arabinose. [Reena et al , 1968].

\section{Conclusion}

As we know the synthetic drugs are efficient to treat diseases, but are not devoid of remarkable side effects. In consideration to this aspect demand to herbal drugs is increasing. Plants contain number of chemical moieties with varied pharmacological activities. Many potent and efficacious medicinal principles used for treating dreadful diseases have been isolated from plant kingdom. So it is very clear that the study of the medicinal plants is important to meet the requirements in effective therapy. This article presented the research work so far done on the plant Lannea coromandelica (Houtt.) Merr. Hopefully this work may help the future researchers to adopt the methods of extraction, isolation of the chemical constituents of the plant in treatment of diseases. There is a visible scope for the development of lead molecules from the plant for the effective treatment of ulcers, cancer, sterility, pains which demands for new drugs aiming at safety and efficacy in their treatment. Finally, It concludes that this plant requires a huge research yet to be done in support to the traditional claims. Considering the distribution, range of medicinal properties, the chemical constituents of the plant, one can absolutely say it deserves the title 'THE RESEARCHER'S TREE'.

\section{References}

1. Rahman, M.; Khatun, A.; Uddin, S.J.; Shilpi, J.A., Comparative effect of Lanneacoromandelica leaves sten and bark on acetic acid indued pain model in mice and chromogenic reagents: exploring the analgesic potentialand phytochemical group, Pharmacologyonline, 2016 • vol.1 • 146-152

2. R.K Waghmare , S.S. Deokule , Botanical Standardization of Bone setting Plant Lanneacoromandelica., International Journal of Innovative Science, Engineering \& Technology, Vol. 1 Issue 6, August 2014.278281

3. N. Santhi Priya*, M. Santhosh Aruna, D. Eswar Tony, Rama Rao Nadendla ,Pharmacological evaluation of extract of Lanneacoromandelica(Linn) for its antiulcer activity in rodents, Scholars Academic Journal of Pharmacy, 2015; 4(4): 217-221

4. R. Sathish, Mohdhasib Ahmed, K. Natarajan, K.G. Lalitha Evaluation of wound healing and antimicrobial activity of Lannea coromandelica , Journal of Pharmacy Research 2010, 3(6), 1225-1228

5. Kaur R, Jaiswal M.L., Jain V. Preliminary Pharmacognostical\& Phytochemical investigation of Bark \& Leaves of Lannea coromandelicaHoutt. Merrill., International Journal of Pharmacognosy and Phytochemical Research 2012; 4(3); 82-88

6. Avinash Kumar Reddy et al. ,Lannea coromandelica: The Researcher's Tree , International Journal of Pharmacy Practice \& Drug Research 2011,4(3),577-579

7. N. Santhi Priya, et al, Pharmacological evaluation of extract of Lannea coromandelica(Linn) for its antiulcer activity in rodents, Scholars Academic Journal of Pharmacy, 2015; 4(4): 217-221

8. Md. Arif Wahid, In vitro Phytochemical and biological Investigation of plant Lannea coromandelica, Thesis Paper, submitted to 
the Department of Pharmacy, East West University, Dhaka.2009

9. Md. Jakir Hossain, et al, Phytochemical Screening, Antimicrobial Activity, Antioxidant Capacity And In Vivo Anticancer Activity Of Lannea Coromandelica Bark Extracts, Journal of Pharmacy and Biological Science, Volume 13, Issue 3 Ver. II, 2018, PP 19-25

10. K. Vadivel, et al , Priliminary phytochemical evaluation of leaf extract of Lannea coromandelica , International Journal of Pharmacology Research, Vol 2 , Issue 2,2012 , 64-68.

11. Merlin Franco F, Narasimhan D, Plant names and uses as indicators of knowledge patterns, Indian ,Journal of Traditional Knowledge, 8(4), 2009, 645.

12. Heda Nilesh Kamalkishor and Kulkarni, Fish stupefying plants used by Gond tribal of mendha village of central india, Indian Journal of Traditional Knowledge, 8(4), 2009, 531.

13. Md. Manzur-ul-Kadir Mia, Mohammad Fahim Kadir, Md. Shahadat Hossan, Mohammed Rahmatullah, Medicinal plants of the Garo tribe inhabiting the Madhupur forest region of Bangladesh, American-Eurasian Journal of Sustainable Agriculture, 3(2), 2009, 165.

14. Dastur, 2006, Useful Plants of India and Pakistan

15. Useful Tropical Plants Database, Ken Fern, 2014, http://tropical.theferns.info

16. Mohammad S. Rahman, Bilkis Begum, Rasheduzzaman Chowdhury, Khondaker M Rahman,

17. Mohammad A Rashid, Preliminary Cytotoxicity Screening of Some Medicinal Plants of Bangladesh, Dhaka Univ J Pharm Sci, 7(1), 2008, 47.

18. Prabhat Kumar Rai, Lalramnghinglova $\mathrm{H}$, Ethnomedicinal Plant Resources of Mizoram, India: Implication of Traditional Knowledge in Health Care System, Ethnobotanical Leaflets, 14, 2010, 274.

19. http://www.goacom.com/goafoundation/biodi versity

20. Bharath Kumar R, Flora of Sacred Groves at Sriharikota Island, Andhra Pradesh, India, Ethnobotanical Leaflets, 14, 2010, 420.

21. Chopra, 1956, Glossary of Indian medicinal plants

22. Khare, 2007, Indian Medicinal Plants, An Illustrated Dictionary
23. Quattrocchi, 2012, CRC World Dictionary of Medicinal and Poisonous Plants

24. 23)Ken Fern, Useful Tropical Plants Database, http://tropical.theferns.info,2014

25. John H Beaman, Allergenic Asian Anacardiaceae, Clinics in Dermatology, 4(2), 1986, 193

26. Reena Ramachandran, Bhuwan C Joshi, Examination Of The Gum From LanneaCoromandelica, Phytochemstry, 7, 1968, 2057.

27. Anderson DMW, Hendrie A, The Structure OfLameaCaromandelica Gum, Carbohydrate

28. Research, 26, 1973, 105

29. Clarke AE, Anderxn RL, Stone BA, Form and Function of Arabinogalactans and Arabinogalactan- Proteins, Phytochemistry, $18,1979,521$

30. EckhardWollenweber and Volker H Dietz, Occurrence And Distribution of Free Flavonoid Aglycones in Plants, Phytochemistry, 20(5), 1981, 869.

31. Venkata ratnam $\mathrm{K}$ and Venkata rajuRR,Traditional medicine used by the adivasis of

32. eastern Ghats, Andhra Pradesh - For bone fractures, Ethnobotanical leaflets 12, 2008,1922.

33. Sankara Subramanian S, Nair AGR, Angiospermae DicotyledonaeAnacardiaceae Polyphenols of LanneaCoromandelica, Phytochemistry, 10, 1971, 1939

34. "Lanneacoromandelica". The Plant List. Version 1. 2010. Retrieved 4 January 2014.

35. Lanneacoromandelica, on Useful Tropical Plants, at http://tropical.theferns.info/viewtropical.php?i $\mathrm{d}=$ Lannea+coromandelica. Accessed 22.8.2017.

36. Katupotha, Jinadasa\&Kodituwakku, Kusumsiri., Diversity of Vegetation Types of the Pidurangala Granitic Inselberg with Ancient Forest Monastery, Near Sigiriya, Sri Lanka: A Preliminary Study. Research Publication to Commemorate 125 years of service by the Department of Archaeology. Department of Archaeology. 157-167., 2015

37. Dewasya Pratap Singh, Harshika Awasthi, Athar Husain, Amit Kaushik, DayanandanMani , Importance of herbal medicine science ancient time period, Herbal Medicinal Products Department, CSIRCentral Institute of Medicinal and Aromatic Plants, Lucknow- 226015, UP. 
38. Sissi Wachtel-Galor and Iris F. F. Benzie. Herbal Medicine An Introduction to Its History, Usage, Regulation, Current Trends, and Research Needs https://www.ncbi.nlm.nih.gov/books/NBK927 73/\#ch1_sec1

39. Edward, A.; 2001; Pathogenesis Justicia adhatoda (ed) New, Old and Forgotten remedies :pp

40. 210-220.

41. Shinwari, M. I. and Khan, M. A.; 1998; Indigenous use of medicinal trees and shrubs of

42. Margalla Hills National Park, Islamabad; Pak. J. Forest; 48(1-4): 63-90.

43. Zaidi, S. H.; 1998; Existing indigenous medicinal plant resources of Pakistan and their

44. prospects for utilization.Pakistan Forest Jour.; 48(2): 5-10

45. A. S. Bagad, J. A. Joseph, N. Bhaskaran, and A. Agarwal, "Comparative evaluation of antiinflammatory activity of curcuminoids, turmerones, and aqueous extract of Curcuma longa," Advances in Pharmacological Sciences, vol. 2013, Article ID 805756, 7 pages, 2013.

46. M. Ghasemian and M. B. Owlia, "A different look at pulsed glucocorticoid protocols; is high dose oral prednisolone really necessary just after initiation of pulse therapy?" Journal of Case Reports in Practice, vol. 3, no. 1, pp. 1-3, 2015.

47. Reena Ramachandran, Bhuwan C Joshi, Examination Of The Gum From LanneaCoromandelica, Phytochemstry, 7, 1968, 2057.

48. Anderson DMW, Hendrie A, The Structure OfLameaCaromandelica Gum, Carbohydrate Research, 26, 1973, 105

49. Md. Manzur-ul-Kadir Mia, Mohammad Fahim Kadir, Md. Shahadat Hossan, Mohammed Rahmatullah, Medicinal plants of the Garo tribe inhabiting the Madhupur forest region of Bangladesh, American-Eurasian Journal of Sustainable Agriculture, 3(2), 2009,

50. 